\title{
ensaio
}

\section{O INSTRUMENTO DIALÉTICO-AXIOLÓGICO NA SELEÇÃO DE FALAS SIGNIFICATIVAS: EM BUSCA DE UMA EDUCAÇÃO CIENTÍFICA ÉTICO-CRÍTICA}

\author{
Jefferson da Silva Santos ${ }^{1}$ \\ https://orcid.org/0000-0002-8313-4973
}

\author{
Simoni Tormöhlen Gehlen² \\ https://orcid.org/0000-0002-9786-3392
}

\section{RESUMO:}

As discussões sobre a dimensão axiológica na educação têm chamado a atenção de pesquisadores que investigam as possibilidades do desenvolvimento de uma Educação Científica ético-crítico, que considere os valores fundamentais à humanização dos educandos. Nessa perspectiva, o objetivo deste estudo consiste em explicitar a estruturação de um Instrumento dialético-axiológico e analisar suas contribuições para a identificação dos valores e desvalores no processo de obtenção dos Temas Geradores que nortearam a organização das atividades de um Clube de Ciências. Dentre os resultados, destaca-se que o Instrumento permitiu tanto a compreensão da dimensão valorativa nas limitações explicativas dos participantes da Investigação Temática quanto a orientação de quais valores são necessários para superar as situações-limites identificadas, viabilizando uma práxis axiológica no Ensino de Ciências.

\section{EL INSTRUMENTO DIALÉCTICO-AXIOLÓGICO EN LA SELECCIÓN DE DISCURSOS SIGNIFICATIVOS: EN BUSCA DE UNA EDUCACIÓN CIENTÍFICA ÉTICO-CRÍTICA}

\section{RESUMEN:}

Las discusiones sobre la dimensión axiológica en la educación han llamado la atención de investigadores que estudian las posibilidades de desarrollar una Educación Científica ético-crítica, que considere los valores fundamentales a la humanización de los estudiantes. En esta perspectiva, el objetivo de este estudio es explicar la estructuración de un Instrumento dialéctico-axiológico y analizar sus aportes a la identificación de valores y devaluaciones en el proceso de obtención de los Temas Generadores que orientaron la organización de actividades de un Club de Ciencias. Entre los resultados, se destaca que el Instrumento permitió tanto la comprensión de la dimensión evaluativa en las limitaciones explicativas de los participantes de la Investigación Temática como la orientación de qué valores son necesarios para superar las situaciones límite identificadas, posibilitando una praxis axiológica en la Enseñanza de las Ciencias.

\section{Palavra-chave: \\ Valores; \\ Investigação Temática; \\ Paulo Freire.}

Palabras clave:

Valores;

Investigación Temática; Paulo Freire.

\footnotetext{
1 Universidade Federal de Santa Catarina, Programa de Pós-Graduação em Educação Científica e Tecnológica, Florianópolis, SC, Brasil.

2 Universidade Estadual de Santa Cruz, Programa de Pós-Graduação em Educação em Ciências e Matemática, Ilhéus, BA, Brasil.
} 


\title{
THE DIALECTIC-AXIOLOGICAL INSTRUMENT IN THE SELECTION OF SIGNIFICANT SPEECHES: IN SEARCH OF ETHICAL-CRITICAL SCIENTIFIC EDUCATION
}

\begin{abstract}
:
Discussions about the axiological dimension in education have drawn the attention of researchers who investigate the possibilities of developing an ethical-critical Scientific Education that considers the fundamental values for the humanization of students. In this perspective, the aim of this study is to explain the structuring of a dialectic-axiological instrument and to analyze its contributions to the identification of values and devaluations in the process of obtaining the Generating Themes that guided the organization of activities of a Science Club. Among the results, it is noteworthy that the Instrument allowed both the understanding of the evaluative dimension in the explanatory limitations of the participants of Thematic Research and the orientation of which values are necessary to overcome identified limit situations, enabling an axiological praxis in Science Education.
\end{abstract}

Keywords:

Values;

Thematic Research;

Paulo Freire.

\section{INTRODUÇÃO}

Discussões acerca do papel dos valores nos processos de ensino-aprendizagem, na organização curricular, na avaliação, na formação de professores, têm chamado a atenção de alguns pesquisadores da Educação (Araújo, 2008; Goergen, 2005; Pereira et al., 2017; Virães, 2013). No âmbito escolar, os valores se caracterizam como importantes ferramentas tanto de compreensão quanto de transformação social, pois uma das principais funções da escolarização é oportunizar a inserção dos educandos à determinados costumes, hábitos e valores compartilhados socialmente (Barrere; Martuccelli, 2001).

Ao contribuir com as investigaçóes sobre a importância dos valores no contexto educativo, estudos da área de Educação em Ciências têm abordado questôes como: a necessidade em considerar os valores nos processos formativos de professores, em razão de que todas as relaçôes humanas são orientadas por valores, traduzindo "as preferências, os motivos e os critérios de conduta das pessoas, incluindo as perspectivas do ensino e da aprendizagem” (Lucas et al., 2016, p. 500); a imprescindibilidade de discutir, a partir das relaçôes entre Ciência, Tecnologia e Sociedade (CTS), que os diferentes tipos de valores (epistemológicos, sociais, históricos, éticos etc.) são fundamentais para a compreensão dos propósitos da produção científico-tecnológica (Roso, 2017); a discussão sobre como os valores, no Ensino de Ciências, que podem viabilizar a superação dos processos de ensino-aprendizagem que perpetuam uma concepção positivista de Ciência e Tecnologia (Raicik; Angotti, 2019).

Conforme Auler (2018), a questão dos interesses e valores que norteiam a produção científico-tecnológica indica a necessidade da reflexão sobre os valores que traduzem as demandas populares, como forma de desenvolver uma Ciência comprometida com a realidade social, contra-hegemônica. Pesquisadores têm salientado a importância em se discutir criticamente as relações entre Ciência, Tecnologia e Sociedade, principalmente por meio do Ensino de Ciências, com o objetivo de propiciar outras maneiras de compreender e produzir Ciência e Tecnologia, considerando a dimensão axiológica envolvida nesse contexto (Auler, 2002; Rosa, 2014; Roso, 2017; Santos; Auler, 2019).

Com o propósito de desenvolver uma perspectiva alternativa da produção científico-tecnológica e da Educação em Ciências, em que as demandas populares são identificadas para que sirvam de ponto de partida para a elaboração de possíveis soluções às contradições sociais, destaca-se a importância da Investigação Temática como uma maneira de compreender a realidade em determinada localidade e promover uma cultura 
de participação por meio da educação e de iniciativas populares (Auler; Dalmolin; Fenalti, 2009; Nascimento; Von Linsingen, 2006; Roso et al., 2015; Santos et al., 2019). Nessa conjuntura, a investigação sobre a dimensão axiológica se revela fundamental para a compreensão de como a comunidade local entende os problemas que existem na localidade em que vivem, para o desenvolvimento coletivo de possíveis alternativas a esses problemas, na desmistificação da neutralidade e imparcialidade científico-tecnológica e na cultura de participação envolvendo educandos, educadores, pesquisadores e comunidade.

Contudo, questiona-se: de que maneira os valores podem ser identificados? Como os valores podem contribuir para a organização de programas escolares na Educação em Ciências? Ao considerar a importância da dimensão axiológica para uma prática educativa ético-crítica na Educação em Ciências, o presente estudo tem como objetivo explicitar o processo de construção de um Instrumento dialético-axiológico para selecionar falas significativas durante a obtenção de Temas Geradores, bem como analisar as contribuições deste instrumento para a identificação dos valores e desvalores neste processo. Para essa análise, foram consideradas as informações obtidas durante a reestruturação das atividades, como base na Abordagem Temática Freireana, do Clube de Ciências do Centro Integrado Oscar Marinho Falcão (CIOMF), localizado no município de Itabuna/BA.

\section{A SELEÇÃO DE FALAS SIGNIFICATIVAS NA INVESTIGAÇÃO TEMÁTICA}

A Investigação Temática se constitui como um aporte teórico-metodológico que, alicerçada na dialogicidade, problematização, humanização, conscientização e emancipação, visa à libertação dos sujeitos que se encontram em situação de opressão (Freire, 1987). De acordo com Dussel (1977), o processo de libertação é comunal e deve emergir da própria comunidade de vítimas, pois com um projeto de libertação não se pretende promover soluções assistencialistas, mas apresentar alternativas para que os sujeitos possam superar as contradições sociais, respeitando a sabedoria popular e seus valores, à medida que vão tornando-se conscientes das dinâmicas sociais e autônomos nas percepções das injustiças sociais.

Desenvolvida incialmente por Paulo Freire para viabilizar uma alfabetização com sentido e significado aos jovens e adultos do sertão do nordeste brasileiro, a Investigação Temática foi, posteriormente, adaptada por Delizoicov (1991) para o âmbito da educação escolar em cinco etapas:

1. Levantamento Preliminar: momento em que são realizadas conversas informais com os sujeitos imersos na realidade da comunidade investigada, com o objetivo de conhecer a localidade baseando-se na perspectiva dos moradores. Além disso, são utilizadas informações de fontes secundárias, como rádio, TV, jornal, internet etc., possibilitando a elaboração de um dossiê.

2. Codificação: com base nas informaçóes obtidas na etapa anterior, são organizados os relatos dos moradores que podem revelar situaçôes-limites, pois há a possibilidade de os discursos dos sujeitos estarem limitados a explicações fatalistas, indicando um estado de acomodação ou naturalização das contradições sociais.

3. Descodificação: nesta etapa há um retorno à comunidade, em que são apresentadas algumas situações problemáticas aos moradores, para que possam expressar a percepção que possuem sobre a própria condição existencial (Fonseca, 2017). Nesse momento de diálogos e problematizaçôes, os moradores podem legitimar ou não as situações-limites indicadas no processo de codificação. Portanto, nos diálogos descodificadores:

Estarão os homens exteriorizando sua visão do mundo, sua forma de pensá-lo, sua percepção fatalista das "situações-limites", sua percepção estática ou dinâmica da realidade. E nesta forma expressada de pensar o mundo fatalistamente, de pensá-lo dinâmica ou estaticamente, na maneira como realizam seu enfrentamento com o mundo, se encontram envolvidos seus "temas geradores". (Freire, 1987, p.56). 
O Tema Gerador sintetiza as percepçóes do coletivo de sujeitos que compartilham, em determinada localidade, condições sociais semelhantes.

4. Redução Temática: por contemplar diversos aspectos da realidade, o Tema Gerador viabiliza uma organização curricular em que são consideradas diversas áreas do conhecimento. Assim, a Redução Temática consiste em sistematizar os conteúdos, conceitos, açôes e práticas necessárias à compreensão do Tema Gerador. Para possibilitar o diálogo entre as diferentes percepçôes acerca da realidade local e facilitar o processo de organização dos conhecimentos e práticas, Silva (2004) elaborou uma estrutura denominada Rede Temática, caracterizada da seguinte maneira:

Figura 1. Síntese da Rede Temática, adaptada de Silva (2004).

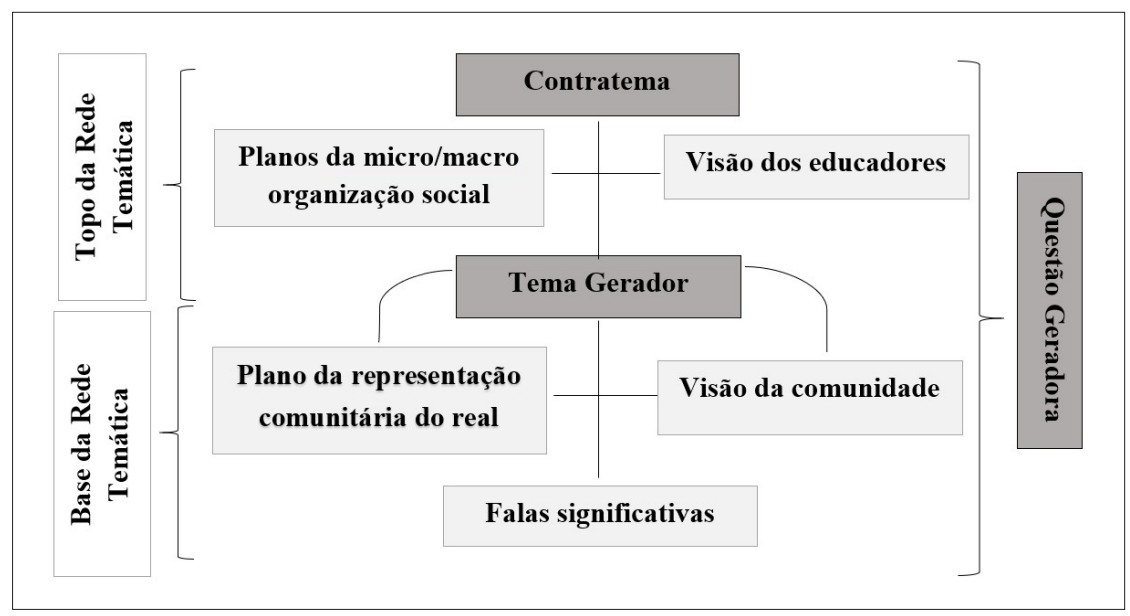

Fonte: Fonseca (2017, p. 89).

Na base da Rede Temática são organizadas as falas significativas que representam a compreensão das situações problemáticas compartilhadas comunitariamente. Nessas representações são identificadas, explícita ou implicitamente, contradiçôes sociais e situaçôes-limites que norteiam a elaboração de planos e açôes de superação dos problemas coletivos da comunidade (Silva, 2004). No topo são sistematizados os conhecimentos e ações como possibilidades de superação das situações-limites salientadas na base da Rede Temática, ou seja, indica a visão dos educadores e pesquisadores sobre como superar as demandas da comunidade. Além disso, há o Contratema, a antítese do Tema Gerador (Silva, 2004, p. 229).

É importante destacar que ao utilizar a Rede Temática em processos formativos de professores foi desenvolvido, no contexto do Grupo de Estudos sobre Abordagem Temática no Ensino de Ciências (GEATEC), o Ciclo Temático, que é uma ferramenta pedagógica em que se evidencia as causas e consequências das contradiçốes sociais existentes na comunidade, além de alternativas de superação das situaçôes-limites, auxiliando na estruturação das Unidades de Ensino (Milli; Almeida; Gehlen, 2018). No planejamento das atividades didático-pedagógicas, os Três Momentos Pedagógicos (3MP) têm sido uma dinâmica utilizada em processos educativos comprometidos com a realidade histórica, social e política dos educandos, pois consiste em: Problematização Inicial (PI) - momento em que se realizam diálogos críticos entre educadores e educandos, sobre aspectos e situaçôes problemáticas da realidade em que vivem; Organização do Conhecimento (OC) - etapa na qual alguns conteúdos e conhecimentos são sistematizados a fim de viabilizar uma compreensão crítica das causas e consequências dos problemas discutidos na PI; Aplicação do Conhecimento (AC) - momento de síntese entre as discussóes da PI e os conhecimentos construídos na OC, propiciando a compreensão sobre possíveis soluções para as situações problemáticas que nortearam a aula e o desvelamento de outras situações que necessitam ser problematizadas (Delizoicov; Angotti; Pernambuco, 2011).

5. Desenvolvimento em Sala Aula: etapa de implementação das atividades didático-pedagógicas estruturadas nos 3MP e baseadas em um Tema Gerador. 
Nessa perspectiva, as três primeiras etapas da Investigação Temática (Levantamento Preliminar, Codificação e Descodificação) centram-se nas falas dos sujeitos, concedendo voz aos excluídos pelo sistema hegemônico. Por meio dessas falas, busca-se compreender e legitimar os problemas emergentes da condição existencial desses sujeitos. No entanto, a compreensão fenomenológica das contradiçôes sociais demanda o entendimento hermenêutico que o oprimido expressa ao relatar aspectos inerentes a sua realidade, pois a manifestação do mundo do outro está para além de uma análise unicamente fenomenológica, haja vista que se necessita considerar a dimensão ética em que o outro é percebido "não apenas como coisa, mas como 'Outro', no momento em que esse 'Outro' nos interpela: aspecto específico do ser humano. Momento em que chamo a minha responsabilidade pelo outro" (Brick, 2017, p. 149). Ou seja, o problema necessita ser considerado a partir do ponto de vista do sujeito que vive a contradição social, o que viabiliza o desvelamento do mundo do "outro".

Diante dessa dificuldade, Silva (2004) elaborou alguns critérios para facilitar a seleção das falas significativas que revelam as demandas da comunidade, apresentados no Quadro 1:

\section{Quadro 1. Procedimento para a seleção das falas significativas}

\section{Critérios para a seleção das falas significativas}

Devem ser selecionadas falas que expressem visões de mundo, ou seja, descrições da realidade local não são suficientes. Devem ser falas explicativas, propositivas e abrangentes, que extrapolem a simples constatação ou descrição da realidade local - e não situações restritas a uma pessoa ou à família -, que expressem opinião e envolvam de algum modo as situações reais vivenciadas pela coletividade;

As falas precisam expressar problemas e necessidades, possibilitando perceber o conflito cultural, a contradição social, caracterizando situações significativas do ponto de vista da (s) comunidade (s) investigada (s);

O número de falas destacadas orienta-se pelo grau de saturação na análise dos dados - não há um número mínimo, nem máximo a ser observado, o requisito é que representem uma totalização orgânica;

Devem representar uma situação-limite, ou seja, um limite explicativo na visão da comunidade a ser superado (senso comum), caracterizando-se como um contraponto à visão diferenciada do educador;

Dentro do possível, devem ser resgatadas falas como originalmente aparecem, ou seja, "sem o filtro linguístico" do pesquisador, com gírias e dialetos - as observações, inferências e interpretação do grupo pesquisador são imprescindíveis e inevitáveis, todavia na seleção é desejável que sejam contempladas e respeitadas as falas da (s) comunidade (s) e do (as) aluno (as) em suas expressões originais;

Devem abordar questões recorrentes da realidade local e apresentar algum grau de dissociação entre as diferentes dimensões e planos da realidade (aspectos amplos da macro organização sociocultural e econômica não articulados às situações significativas vivenciadas);

Geralmente o limite explicativo aparece de forma explícita e pragmática no discurso da comunidade, entretanto, quando marcada pela baixa autoestima, pode estar implícita em muitas situações e discursos, em diferentes formas de expressão;

Contextualizar sempre as falas selecionadas (compreensão dos processos de construção dos paradigmas explicativos da realidade);

A seleção se dá por contradições, por diferenças nas visões de mundo e concepções da realidade concreta entre educadores e comunidade (evitar escolha narcisista, do idêntico);

Toda fala significativa é significativa porque demanda um patamar analítico (epistemológico) desconhecido para o "outro" - referencial diferenciado do pesquisador;

É, portanto, fundamental apreender os conceitos cotidianos e as obviedades presentes nas explicações e proposições presentes na leitura de mundo da comunidade;

É imprescindível perceber que as diferenças entre as concepções de realidade (de educadores e educandos) baseiamse em referenciais epistemológicos distintos, vão além das informações sobre o real, para uma fundamentação conceitual analítica e relacional;

Ao selecionar uma fala significativa, já estamos, implícita ou explicitamente, relacionando informações e conceitos epistemológicos analíticos a serem trabalhados por diferentes áreas e disciplinas.

Fonte: Silva (2004, p. 436). 
Os critérios propostos por Silva (2004) permitem a seleção de falas coletivas, que são falas representativas de situações problemáticas, selecionadas de acordo com a identificação de uma leitura de mundo recorrente em determinado grupo de pessoas, reflexo do contexto comunitário em que vivem. Portanto, as falas significativas são meios para a compreensão de determinada localidade, segundo o ponto de vista do outro.

Sobre o entendimento do problema com base na perspectiva de quem o vivencia, estudos em Educação em Ciências, que realizaram a Investigação Temática, têm sinalizado algumas dificuldades em identificar as contradiçôes sociais a partir da visão de mundo dos sujeitos coletivos. Destes estudos, destacam-se: Sousa (2015) que teve como hipótese inicial problemas como saneamento básico, abastecimento de água e violência/tráfico no bairro Banco da Vitória, Ilhéus/BA, e, por meio de um círculo de cultura, ${ }^{1}$ composto principalmente por educadores que também são moradores da comunidade, houve a legitimação do problema relacionado aos diversos tipos de água (cisterna, rio, minadouro e água da torneira). No entanto, a autora não explicita os critérios utilizados para selecionar as falas que legitimaram a situação-limite evidenciada no estudo; no trabalho de Miranda, Braibante e Pazinato (2015), durante o Levantamento Preliminar e a Codificação emergiram muitos problemas associados às drogas, saúde, educação, lazer, infraestrutura etc., e na legitimação do Tema Gerador os autores utilizaram somente o critério de saturação para priorizar as falas significativas que mencionavam as drogas. Com isso, questiona-se se o critério de saturação é de fato suficiente na legitimação de um problema significativo e emergente para a comunidade; Mendonça (2016) apresenta um processo formativo de professores baseado na Investigação Temática, em que diversos problemas são identificados, como violência, drogas, desemprego, falta de saneamento básico etc., mas o critério de seleção das falas significativas também não é explicitado.

Ressalta-se que, no contexto de uma sistematização curricular de Ciências, por meio da Abordagem Temática Freireana, o estudo de Demartini e Silva (2013) indica que os valores se constituem como um dos aspectos importantes a serem observados nas falas significativas, contribuindo para a compreensão das situações-limites. Assim, evidencia-se que os critérios elaborados por Silva (2004) são imprescindíveis para a seleção das falas significativas e para a compreensão das contradiçôes sociais, a partir do ponto de vista dos sujeitos que as vivenciam. Contudo, há possibilidade de ampliação desses critérios por meio de uma estratégia ou instrumento pedagógico que considere os valores no processo de seleção das falas significativas.

A percepção sobre o modo como os sujeitos valoram seu mundo pode auxiliar na compreensão da sua condiçãa existencial, pois:

[...] sempre que reconhecemos algo como 'valioso' estamos, em última análise, atribuindo-lhe valor ou, como parece ser mais adequado, estamos emitindo 'juízos de valor'. Valoramos diferentes coisas: opinióes, atitudes, objetos, etc. Mas esses juízos de valor não são emitidos univocamente. Nossos juízos valorativos são polarizados, ou seja, julgamos coisas como valiosas ou desvaliosas, atribuindo-lhes valores positivos ou negativos (valor, desvalor). (Lucas, 2014, p. 29).

Por um lado, tudo que possui valor para o sujeito não indica explicitamente um problema, por outro, tudo que representa um desvalor aponta para situações problemáticas, segundo a sua percepção da realidade. Portanto, a identificação dos valores e desvalores nos diálogos com os moradores de uma comunidade pode auxiliar na compreensão dos problemas, a partir da percepção de quem os vivencia. Ao considerar os aportes teórico-metodológicos da pedagogia freireana, da filosofia dusseliana e da praxiologia patriciana, foi construído o Instrumento dialético-axiológico com a finalidade de viabilizar a identificação de valores e desvalores nos discursos que expressam as visóes de mundo dos participantes da Investigação Temática. 


\section{PERCURSOS METODOLÓGICOS NA ELABORAÇÃO DO INSTRUMENTO DIALÉTICO-AXIOLÓGICO}

O desenvolvimento do Instrumento dialético-axiológico demandou uma busca por estudos na área de Educação em Ciências que investigam como os valores podem viabilizar um sistema educativo que considera a dimensão axiológica na formação de professores, organização curricular, desenvolvimento de atividades didático-pedagógicas etc. Nessa conjuntura, no estudo de Lucas (2014) os referenciais da axiologia são transpostos para o âmbito da Educação em Ciências, o que possibilitou a estruturação do Instrumento analítico-axiológico facilitando a identificação e a análise dos valores envolvidos no processo de formação inicial de professores de biologia, tendo como parâmetro a percepção dos formadores e dos graduandos.

Ao considerar a proposta de Lucas (2014) e os referenciais freireanos utilizados por pesquisadores em Educação em Ciências, seguiram-se as seguintes etapas: a) Análise das potencialidades e limitaçôes do Instrumento analítico-axiológico (Lucas, 2014); b) Sistematização de pressupostos teórico-metodológicos para a identificação de valores na Investigação Temática e c) Estruturação do Instrumento dialético-axiológico.

\section{A) ANÁLISE DAS POTENCIALIDADES E LIMITAÇÕES DO INSTRUMENTO ANALÍTICO-AXIOLÓGICO}

Lucas (2014) desenvolveu uma “Axiologia Relacional Pedagógica” em que se destaca a convergência entre os pressupostos teóricos da axiologia e da educação, possibilitando a elaboração de um Instrumento analítico-axiológico que facilita a identificação dos valores no processo de ensino-aprendizagem e a elaboração de perfis axiológicos.

Quadro 2. Descrição do Instrumento analítico-axiológico, proposto por Lucas (2014)

\begin{tabular}{|c|c|c|}
\hline \multicolumn{3}{|c|}{ Estabelecimento de uma relação } \\
\hline \multicolumn{3}{|c|}{$\begin{array}{l}\text { Descrição/evidenciação da relação estabelecida entre objeto valioso e o sujeito que valora. No caso de uma } \\
\text { entrevista, as próprias perguntas podem sugerir essa relação, agindo como guias para uma valoração. As perguntas, } \\
\text { nesse sentido, levam o entrevistado a refletir sobre uma temática determinada a partir da relação que mantém } \\
\text { com a mesma. Neste setor do instrumento, as perguntas da entrevista são inseridas juntamente com as respostas } \\
\text { transcritas e revisadas pelos entrevistados. }\end{array}$} \\
\hline Objeto valioso & Sujeito que valora & Juízo de valor \\
\hline $\begin{array}{l}\text { Aquilo que está sob valoração. Em } \\
\text { uma entrevista, o objeto valioso } \\
\text { compreende o tema central das } \\
\text { perguntas, ou seja, o assunto } \\
\text { relevante acerca do qual se pretende } \\
\text { obter uma valoração. }\end{array}$ & $\begin{array}{l}\text { o sujeito que valora. Compreende } \\
\text { os sujeitos entrevistados. }\end{array}$ & $\begin{array}{l}\text { A valoração do sujeito acerca do } \\
\text { objeto valioso. Compreende uma } \\
\text { síntese da resposta dada pelo } \\
\text { entrevistado acerca da pergunta } \\
\text { em questão. }\end{array}$ \\
\hline
\end{tabular}

Fonte: Lucas (2014, p. 116).

Como destacado no Quadro 2, o Instrumento analítico-axiológico apresenta os seguintes aspectos: I) Sujeito(s) que valora(m) - são os indivíduos que emitem valor, tendo como pressuposto sua relação com os objetos, situaçốes e atitudes valoradas; II) Objeto(s) valioso(s) - ente ou fenômeno sobre o qual o sujeito emite determinado valor; III) Juízo(s) de valor - julgamento do sujeito que valora sobre o objeto valorado.

Segundo Lucas (2014, p. 209), o Instrumento analítico-axiológico auxilia na análise do conteúdo valorativo implícito ou explícito na fala selecionada, "possibilitando elencar hierarquicamente o contingente axiológico das falas segundo o estabelecimento de uma relação entre três componentes básicos: os sujeitos que valoram, os elementos sob juízo valorativo e os valores/desvalores detectados”. 
O Instrumento analítico-axiológico contempla as dimensões fenomenológica e hermenêutica na análise das falas. A dimensão fenomenológica corresponde ao segundo elemento no instrumento, em que o sujeito percebe o objeto e nessa relação desenvolve sua consciência sobre o mundo, haja vista que "a consciência é um movimento de transcendência em direção ao objeto e o objeto se dá ou se apresenta à consciência” (Abbagnano, 1998, p. 438). Nessa relação entre sujeito e objeto, necessariamente são revelados valores que indicam as particularidades de uma cultura, uma época, um povo etc. (Hessen, 1974).

O terceiro elemento do Instrumento analítico-axiológico apresenta uma dimensão hermenêutica, pois se refere à compreensão expressa por meio do diálogo de um sujeito sobre um objeto. Segundo Gadamer (2008), do ponto de vista hermenêutico, a compreensão do sujeito sobre o objeto se realiza com base em um processo de caráter linguístico, em que a linguagem serve de mediadora entre o sujeito que interpreta e seu interlocutor. Ou seja, "a circularidade dialógica da linguagem faz o homem compreender-se no mundo de sentido ao qual pertence, mundo que é social, interativo e linguístico, onde ele encontra com os outros e convive” (Santos, 2014, p. 9).

Todavia, o Instrumento analítico-axiológico contém algumas limitações quando se pensa na sua utilização no contexto da Abordagem Temática Freireana, em razão de que os pressupostos sócio-filosóficos da pedagogia freireana se alicerçam na dialética marxista, como destaca Fernandes (2016, p. 492):

A perspectiva da práxis como uma relação dialética entre teoria e prática em um movimento transformador da realidade é fortemente baseada em Marx, uma vez que refuta a interpretação materialista vulgar da práxis que vê o pensamento apenas como uma influência orientadora sobre a atividade material, prática, da humanidade. Pelo contrário, Marx argumenta que a afirmação da humanidade no mundo objetivo é composta de todos os sentidos, incluindo o pensamento.

Além de serem consideradas as dimensões fenomenológica e hermenêutica, é necessário compreender quais são as condições históricas e materiais que caracterizam as relações dos sujeitos com o mundo. A identificação de quais são os valores que emergem da relação dialética sujeito-mundo exige o entendimento sobre os aspectos políticos, históricos, culturais, materiais e ideológicos que fazem parte da realidade dos indivíduos, haja vista que uma educação ético-crítica se caracteriza por seu compromisso com a justiça social, com a transformação da realidade e com a humanização dos sujeitos (SILVA, 2004).

\section{B) SISTEMATIZAÇÃO DE PRESSUPOSTOS TEÓRICO-METODOLÓGICOS PARA A IDENTIFICAÇÃO DE VALORES NA INVESTIGAÇÃO TEMÁTICA}

No âmbito da Investigação Temática é imprescindível considerar além dos aspectos fenomenológicos e hermenêuticos, a dimensão material, social, política e histórica na comunidade investigada. Nesse sentido, o materialismo histórico-dialético tem sido indicado como um importante aporte teórico-metodológico que propõe uma superação da dicotomia entre sujeito e objeto, permitindo uma interpretação das relações dos sujeitos com o mundo, um "pensamento através da materialidade histórica da vida dos homens em sociedade, isto é, trata-se de descobrir (pelo movimento do pensamento) as leis fundamentais que definem a forma organizativa dos homens durante a história da humanidade” (Pires, 1997, p. 87).

A perspectiva do materialismo histórico-dialético é primordial para a compreensão dos fenômenos, quando se entende que a totalidade se constitui com base no princípio da contraditoriedade e que se realiza por meio dos momentos dialéticos de Tese, Antítese e Síntese, indicando um movimento de transformação permanente da realidade (Fernandes, 2016). No processo de construção da sua proposta pedagógica, Freire (1987) encontrou na dialética marxista a fundamentação teórica para a conceituação de sujeito e de realidade como fenômenos indissociáveis e que possuem uma natureza de inacabamento. Com isso, a pedagogia freireana evidencia que o desvelamento da condição existencial humana se realiza mediante a compreensão das condiçốes materiais e históricas que permeiam suas relaçóes com o mundo, pois: 
Uma unidade epocal se caracteriza pelo conjunto de ideias, de concepçốes, esperanças, dúvidas, valores, desafios, em interação dialética com seus contrários, buscando plenitude. A representação concreta de muitas destas ideias, destes valores, destas concepções e esperanças, como também os obstáculos ao ser mais dos homens, constituem os temas da época. (Freire, 1987, p. 53).

Como destacado por Freire (1987), além dos aspectos históricos e materiais, também é necessário compreender os valores que emergem das relações dialéticas dos sujeitos com o mundo, pois o processo de valoração é relacional. A análise dessas relações, sob uma perspectiva ético-crítica, pode revelar situações de marginalização, silenciamento, invisibilização e exploração das populações em situação de injustiça social (Dussel, 1980). Desse modo, a superação das relações de opressão e dominação depende de um projeto pedagógico libertador que: tenha como ponto de partida a realidade dos oprimidos; conceda espaços para a exteriorização das diferentes percepções da realidade; fomente um senso de responsabilidade mútua; viabilize a participação política e social nas tomadas de decisões; propicie uma práxis de transformação da realidade (Dussel, 1977).

Esse processo de humanização, em que as realidades locais e escolares são indissociáveis, visa a conscientização dos oprimidos para que possam refletir e agir coletivamente contra as estruturas de opressão. Isso significa que a conscientização envolve a compreensão de que alguns valores são impostos como forma de dominação, o reconhecimento do valor das culturas populares, o entendimento de que alguns valores necessitam ser promovidos como forma de fortalecer culturas marginalizadas (Dussel, 2002).

\section{C) ESTRUTURAÇÃO DO INSTRUMENTO DIALÉTICO-AXIOLÓGICO}

Ao considerar indicativos como a importância dos valores para a compreensão de um fenômeno histórico e social (Freire, 1996), as possíveis contribuiçôes dos valores para a seleção das falas significativas no processo de Investigação Temática (Demartini; Silva, 2013) e a possibilidade de utilização de um instrumento que facilite a identificação dos valores nas falas dos sujeitos (Lucas, 2014), propõe-se uma adaptação do Instrumento analítico-axiológico, incorporando algumas características da dinâmica do materialismo histórico-dialético. Nesse sentido, foi elaborado o Instrumento dialético-axiológico (Quadro 3), contemplando a natureza relacional do processo de valoração, os princípios histórico e material fundamentais à compreensão de uma determinada realidade, a escuta sobre o que o outro tem a dizer e a síntese entre as diferentes percepções sobre o mundo, representando um pensamento coletivo.

O Instrumento dialético-axiológico se originou apoiado no entendimento de que os valores e desvalores podem traduzir a compreensão dos sujeitos sobre determinada situação ou objeto, possibilitando o desvelamento de um pensamento coletivo, pois a dimensão axiológica é indissociável das dimensões histórica, social, política e cultural (Hessen, 1974; Lucas 2014; Patrício, 1993). Portanto, este instrumento foi estruturado segundo os princípios do materialismo histórico-dialético, em razão de que a realidade concreta dos indivíduos, que se constitui historicamente, influencia substancialmente no processo de valoração que está em constante construção. 
Quadro 3. Descrição do Instrumento dialético-axiológico

Relação sujeito-mundo

Descrição dos aspectos históricos, políticos, materiais e sociais relacionados ao contexto existencial dos sujeitos que participam das conversas informais na etapa de Levantamento Preliminar.

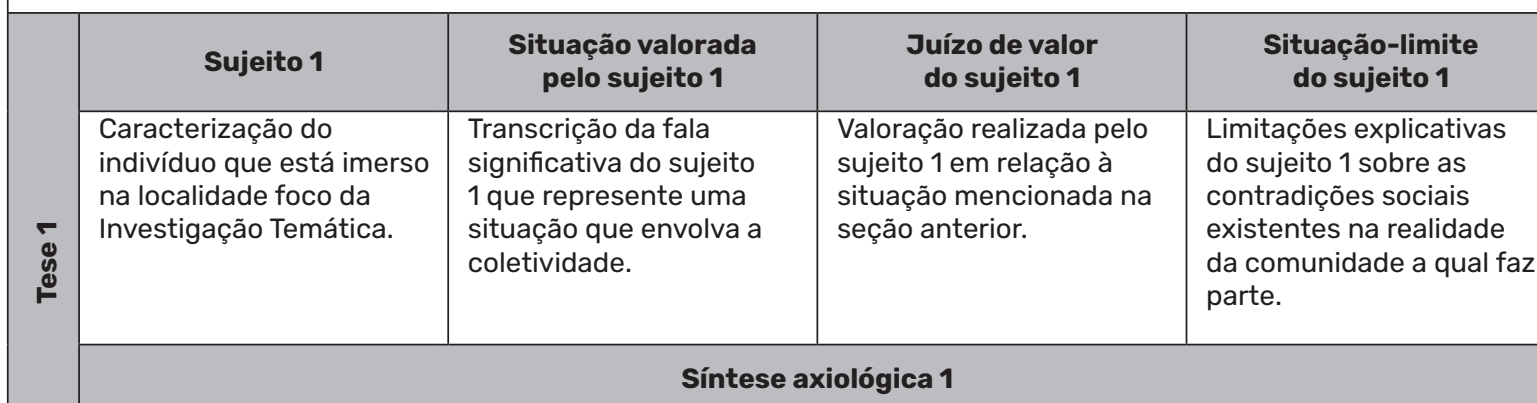

Descrição dos valores e/ou desvalores envolvidos na relação do sujeito 1 com uma situação vivenciada pela comunidade.

\begin{tabular}{|c|c|c|c|c|}
\hline \multirow{3}{*}{  } & Sujeito 2 & $\begin{array}{c}\text { Situação valorada } \\
\text { pelo sujeito } 2\end{array}$ & $\begin{array}{l}\text { Juízo de valor } \\
\text { do sujeito } 2\end{array}$ & $\begin{array}{l}\text { Situação-limite } \\
\text { do sujeito } 2\end{array}$ \\
\hline & $\begin{array}{l}\text { O sujeito } 2 \text { também é } \\
\text { um indivíduo que está } \\
\text { imerso na localidade } \\
\text { foco da Investigação } \\
\text { Temática. }\end{array}$ & $\begin{array}{l}\text { Transcrição da fala } \\
\text { significativa do sujeito } \\
2 \text { referente à mesma } \\
\text { situação coletiva indicada } \\
\text { pelo sujeito } 1 .\end{array}$ & $\begin{array}{l}\text { Valores e/ou desvalores } \\
\text { atribuídos pelo sujeito } \\
2 \text { em relação à situação } \\
\text { mencionada na seção } \\
\text { anterior. }\end{array}$ & $\begin{array}{l}\text { Limitações na } \\
\text { compreensão do sujeito } \\
2 \text { sobre as contradições } \\
\text { sociais na comunidade } \\
\text { em que vive. }\end{array}$ \\
\hline & & & lógi & \\
\hline
\end{tabular}

Descrição dos valores e/ou desvalores emergidos do discurso do sujeito 2 ao pronunciar sua compreensão sobre uma situação vivenciada pela comunidade. É importante destacar que a quantidade de Teses depende da quantidade de sujeitos que participam dos diálogos no Levantamento Preliminar, em que se referem a uma situação em comum.

\section{Tensões axiológicas}

Organização dos discursos de todos os sujeitos axiológicos, que vivem na mesma comunidade, com base nos diferentes sistemas de valores que cada indivíduo possui, possibilitando uma compreensão dos níveis e dimensões do real.

\section{Síntese axiológica geral}

Nesse momento, os desvalores identificados podem indicar uma compreensão coletiva sobre o que a comunidade entende por situação problemática e os valores podem indicar as limitações da comunidade em relação à compreensão das contradições sociais existentes na localidade.

Fonte: Elaborado pelos autores.

O Instrumento dialético-axiológico tem como ponto de partida a relação sujeito-mundo, em que são utilizadas as informações obtidas por meio das conversas informais, realizadas na etapa do Levantamento Preliminar, para que sejam compreendidas as particularidades históricas, políticas e sociais da comunidade foco da Investigação Temática. A compreensão sobre tais aspectos só é possível mediante a escuta da voz do outro, por isso nas conversas informais devem ser realizados questionamentos que propiciem aos sujeitos a exteriorização das suas percepçôes da realidade, evidenciando o modo com que se relacionam com o mundo.

Após o estabelecimento da relação sujeito-mundo, o Instrumento dialético-axiológico apresenta as Teses, em que cada uma representa uma síntese da percepção de cada sujeito sobre a realidade, sendo possível que haja Tese 1, Tese 2, Tese 3 e assim por diante. Essa parte do Instrumento dialético-axiológico se constitui em cinco seçốes, quais sejam: 
Sujeito - Nesta seção são apresentadas algumas características importantes sobre o sujeito que faz parte da comunidade foco da Investigação Temática e que participa do processo de Levantamento Preliminar expressando sua percepção ao longo das conversas informais. Portanto, é imprescindível que nessa seção sejam descritas informações como o tempo que reside e seu papel social na localidade, para que se compreenda qual a relação estabelecida entre o sujeito e a comunidade.

Situação valorada - Esta seção é reservada à transcrição da fala significativa referente a uma situação vivenciada pela comunidade. Como destacado por Silva (2004), uma fala se caracteriza como significativa à medida que evidencia uma situação problemática que envolve não só o próprio sujeito que fala, mas a coletividade.

Juizo de valor - Os juízos de valor são julgamentos sobre alguma coisa com base no sistema de valores que refletem preferências, princípios, hábitos, costumes dentre outras características que compõem a percepção dos sujeitos (Abbagnano, 1998). Por isso, nesta seção, são indicados os valores que emergem da fala significativa do sujeito em relação a uma situação valorada e vivenciada pelos demais sujeitos da comunidade.

Situação-limite - Ao considerar a relação do sujeito com a comunidade, a situação problemática por ele indicada por meio da fala significativa e os valores e/ou desvalores atribuídos a essa situação coletiva, é possível identificar as limitações em sua compreensão, ou seja, aspectos que impedem a percepção da existência das contradições sociais na realidade da comunidade, bem como suas causas, consequências e alternativas de superação.

Sintese axiológica - nessa seção são indicados todos os valores e/ou desvalores que podem emergir do processo de valoração de cada sujeito.

À medida que surgirem novos sujeitos nos diálogos do Levantamento Preliminar, valorando a mesma situação vivenciada pela comunidade, novas seções de Teses irão emergir. Com base nas sínteses axiológicas em cada Tese, no segundo momento do Instrumento são constituídas as Tensões Axiológicas, em que são organizadas as diferentes percepçôes dos sujeitos, permitindo uma análise dos distanciamentos e aproximações acerca do que cada indivíduo expressa como pensamento particular e como pensamento compartilhado coletivamente.

A partir das Tensões Axiológicas, chega-se ao momento da Síntese Geral, no qual é superada a unilateralidade da análise por meio de uma organização das várias partes que compóem o Instrumento dialético-axiológico. Desse modo, os discursos dos diferentes sujeitos podem ser organizados de acordo com os valores e/ou desvalores relacionados a um determinado objeto ou situação em comum. Essa organização permite a identificação de uma unidade axiológica em que, no contexto da Investigação Temática, os valores podem indicar as limitaçôes da comunidade em relação à compreensão das contradições sociais existentes na localidade e os desvalores podem sinalizar uma compreensão coletiva sobre o que a comunidade entende por situação problemática.

No Instrumento dialético-axiológico são priorizadas as relações dos sujeitos com o mundo, a concretude e a historicidade da vida e a escuta do outro, pois, como destaca Dussel (2002), a compreensão da condição existencial e o respeito pelo Ser do outro são os princípios que fundamentam a dialética considerada como analética, isto é, uma dialética aberta à alteridade, aberta às vítimas do sistema-mundo vigente.

\section{A UTILIZAÇÃO DO INSTRUMENTO DIALÉTICO-AXIOLÓGICO NO CLUBE DE CIÊNCIAS DO CIOMF}

Na busca por uma parceria colaborativa entre escola, comunidade e universidade, o GEATEC foi convidado pelo CIOMF para contribuir com a reformulação das atividades do Clube de Ciências da escola. Nesse âmbito, o GEATEC realizou algumas reunióes tanto com os educadores quanto com os estudantes que integram o Clube, com duração de 40 horas, no período entre outubro de 2019 e fevereiro de 2020, para discutir como a perspectiva freireana poderia nortear o processo de desenvolvimento dos projetos de Ciências.

Após as discussões da possibilidade da utilização da Investigação Temática como forma de identificar as demandas de algumas localidades do município de Itabuna/BA, foram formados três grupos com edu- 
cadores orientadores e estudantes de acordo com os bairros em que residiam, quais sejam: Santo Antônio; Lomanto; Pontalzinho. ${ }^{2}$ Em seguida, os grupos foram a campo para realizar o Levantamento Preliminar e algumas das informaçóes obtidas com os moradores do bairro Santo Antônio foram dispostas no Instrumento dialético-axiológico, propiciando a seguinte análise:

\section{Quadro 4. Utilização do Instrumento dialético-axiológico no contexto do bairro Santo Antônio}

\begin{tabular}{|c|c|c|c|c|}
\hline \multicolumn{5}{|c|}{ Relação sujeito-mundo } \\
\hline \multicolumn{5}{|c|}{$\begin{array}{l}\text { O Santo Antônio é um dos maiores bairros de Itabuna/BA. Apesar de ser uma das regiões próximas ao centro da } \\
\text { cidade, os moradores relataram que existem problemas de infraestrutura, como a falta de saneamento básico, de } \\
\text { iluminação e de asfaltamento em algumas ruas, falta de segurança pública etc. }\end{array}$} \\
\hline \multirow{4}{*}{ @্ } & Sujeito 1 & $\begin{array}{c}\text { Situação valorada } \\
\text { pelo sujeito } 1\end{array}$ & $\begin{array}{l}\text { Juízo de valor } \\
\text { do sujeito } 1\end{array}$ & $\begin{array}{l}\text { Situação-limite } \\
\text { do sujeito } 1\end{array}$ \\
\hline & $\begin{array}{l}\text { Homem, } 39 \text { anos, trabalha } \\
\text { como padeiro e vive no } \\
\text { bairro desde que nasceu. }\end{array}$ & $\begin{array}{l}\text { Ao responder uma } \\
\text { pergunta sobre a } \\
\text { existência de alguns } \\
\text { problemas no bairro, } \\
\text { o sujeito } 1 \text { diz: "Esses } \\
\text { problemas (falta de } \\
\text { saneamento, buracos, } \\
\text { violência, som etc.) têm } \\
\text { que ser solucionados, } \\
\text { mas a gente não pode } \\
\text { fazer nada". }\end{array}$ & $\begin{array}{l}\text { O sujeito } 1 \text { compreende } \\
\text { que existem problemas } \\
\text { no bairro e os valora de } \\
\text { maneira negativa. }\end{array}$ & $\begin{array}{l}\text { Acomodação e } \\
\text { compreensão limitada dos } \\
\text { problemas existentes no } \\
\text { bairro. }\end{array}$ \\
\hline & \multicolumn{4}{|c|}{ Síntese axiológica 1} \\
\hline & \multicolumn{4}{|c|}{$\begin{array}{l}\text { Embora o sujeito } 1 \text { atribua uma valoração negativa às situações problemáticas no bairro, não há uma indicação } \\
\text { do seu próprio valor, enquanto integrante da comunidade, na contribuição de possíveis alternativas de } \\
\text { superação dos problemas que ele mesmo admite existir. }\end{array}$} \\
\hline \multirow{4}{*}{ 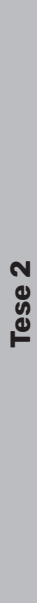 } & Sujeito 2 & $\begin{array}{l}\text { Situação valorada } \\
\text { pelo sujeito } 2\end{array}$ & $\begin{array}{l}\text { Juízo de valor } \\
\text { do sujeito } 2\end{array}$ & $\begin{array}{l}\text { Situação-limite } \\
\text { do sujeito } 2\end{array}$ \\
\hline & $\begin{array}{l}\text { Adolescente, morador do } \\
\text { bairro desde que nasceu, } \\
\text { integrante do Clube de } \\
\text { Ciências da escola. }\end{array}$ & $\begin{array}{l}\text { Ao ser questionado sobre } \\
\text { sua percepção em relação } \\
\text { aos problemas existentes } \\
\text { no bairro, o sujeito } 2 \\
\text { responde o seguinte: } \\
\text { "Na verdade, eu já consigo } \\
\text { dormir com som, porque } \\
\text { eu já me acostumei desde } \\
\text { pequenininha ouvindo som". }\end{array}$ & $\begin{array}{l}\text { O sujeito } 2 \text { convive há } \\
\text { tanto tempo com a } \\
\text { situação da poluição } \\
\text { sonora que se tornou } \\
\text { neutro em relação a ele. }\end{array}$ & $\begin{array}{l}\text { Naturalização e visão } \\
\text { fatalista do problema. }\end{array}$ \\
\hline & \multicolumn{4}{|c|}{ Síntese axiológica 2} \\
\hline & \multicolumn{4}{|c|}{$\begin{array}{l}\text { Embora o sujeito } 2 \text { admita a existência de um problema no bairro, relacionado à poluição sonora, nenhum valor } \\
\text { ou desvalor é atribuído à situação, indicando uma postura de indiferença. }\end{array}$} \\
\hline \multicolumn{5}{|c|}{ Tensões axiológicas } \\
\hline \multicolumn{5}{|c|}{$\begin{array}{l}\text { O sujeito 1, diferentemente do sujeito } 2 \text {, reconhece a existência dos problemas na comunidade e a necessidade de } \\
\text { solucioná-los. No entanto, ambos se isentam da colaboração para uma possível solução à situação, em que o sujeito } 1 \\
\text { apresenta uma postura de passividade, transferindo a responsabilidade e o sujeito } 2 \text { se acomoda e naturaliza o problema. }\end{array}$} \\
\hline \multicolumn{5}{|c|}{ Síntese axiológica geral } \\
\hline & $\begin{array}{l}\text { jeitos } 1 \text { e } 2 \text { mencionam } \\
\text { a situação, negligenciar } \\
\text { formadores daquela reali }\end{array}$ & $\begin{array}{l}\text { oroblema da poluição son } \\
\text { o valor social, cultural, po } \\
\text { le. }\end{array}$ & $\begin{array}{l}\text { a no bairro e explicitam } \\
\text { ico e ético do papel que }\end{array}$ & $\begin{array}{l}\text { a compreensão limitada } \\
\text { suem enquanto agentes }\end{array}$ \\
\hline
\end{tabular}

Fonte: Elaborado pelos autores. 
Por meio do Instrumento dialético-axiológico foi possível compreender algumas situaçóes-limites: o sujeito 1, que reconhece a existência dos problemas na localidade em que vive, mas se isenta do papel de agente transformador da realidade; e o sujeito 2 , que se adaptou à poluição sonora e não atribuiu um juízo valorativo à situação, indicando indiferença, naturalização e acomodação em relação ao problema. Por isso, embora as informações analisadas no Instrumento dialético-axiológico sejam obtidas na etapa do Levantamento Preliminar, é nas etapas de Codificação e Descodificação que a análise se realiza mediante às tensóes entre diferentes perspectivas sobre uma mesma situação problemática.

No Instrumento dialético-axiológico (Quadro 4) constata-se que ambos os sujeitos mencionam a questão da poluiçãoo sonora, mas houve outras situaçóes problemáticas indicadas pelos moradores, como a falta de segurança pública, descaso do poder público com a comunidade, problemas de infraestrutura, etc. Com isso, após os diálogos descodificadores, chegou-se ao Tema Gerador "As percepções de questôes socioambientais dos moradores da comunidade do Santo Antônio" e foi organizado um cartaz, por meio de um trabalho colaborativo entre educadores, educandos e pesquisadores, seguindo a estrutura da Rede Temática, adaptada de Silva (2004).

Na parte inferior desta Rede Temática (Figura 2) foram destacadas as falas significativas dos moradores, educandos e educadores que representam situações-limites, cujas relaçôes entre elas são indicadas pelas setas. A parte superior da Rede Temática se constituiu a partir da visão dos educadores de diferentes áreas sobre os problemas identificados no bairro Santo Antônio, possibilitando a seleção de algumas açóes, conteúdos e conhecimentos que podem contribuir para a compreensão e superação das situações-limites. 
Figura 2. Rede Temática do bairro Santo Antônio, adaptada de Anjos et al. (2020)

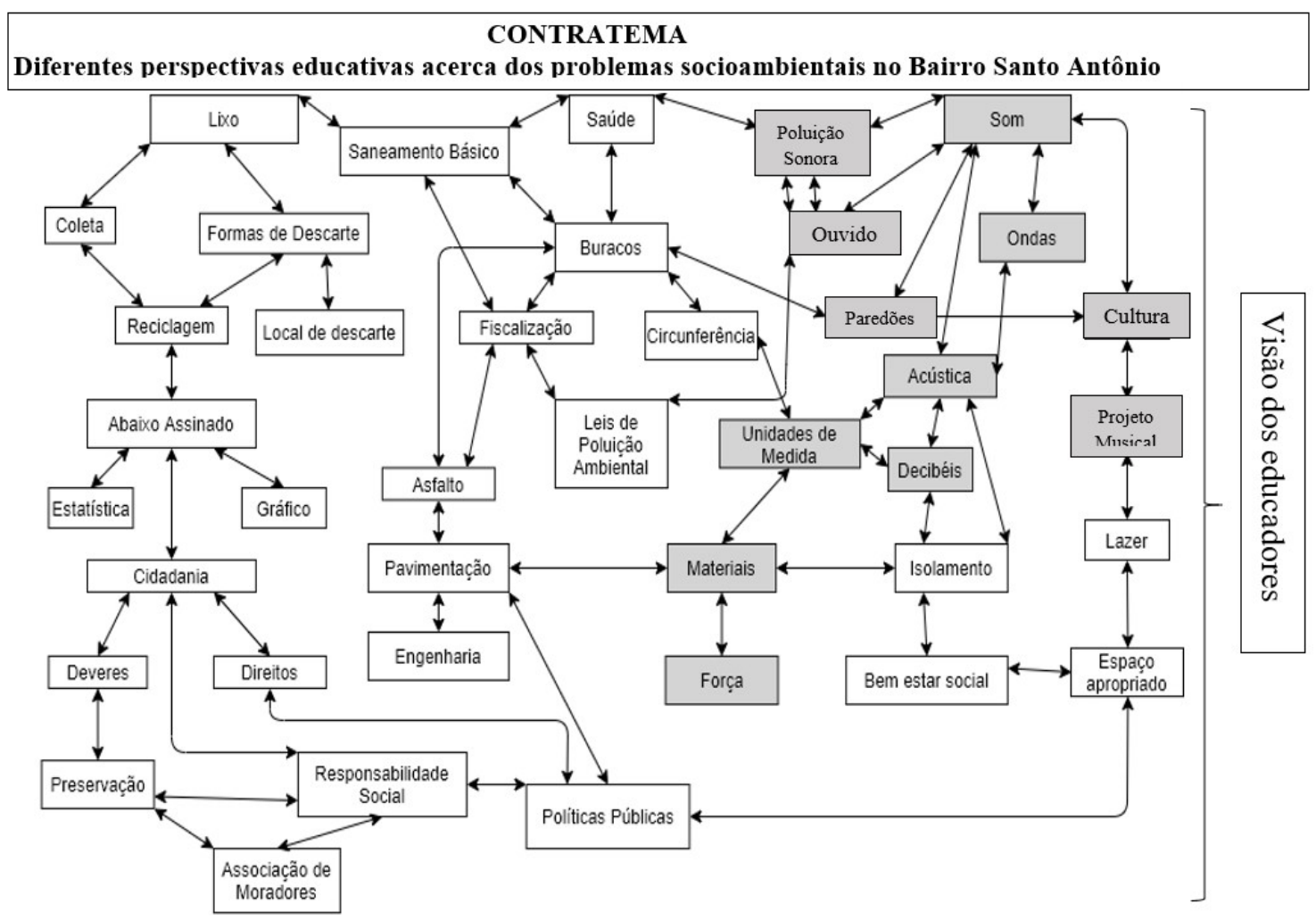

As percepções de questões socioambientais dos moradores da comunidade do Santo Antônio

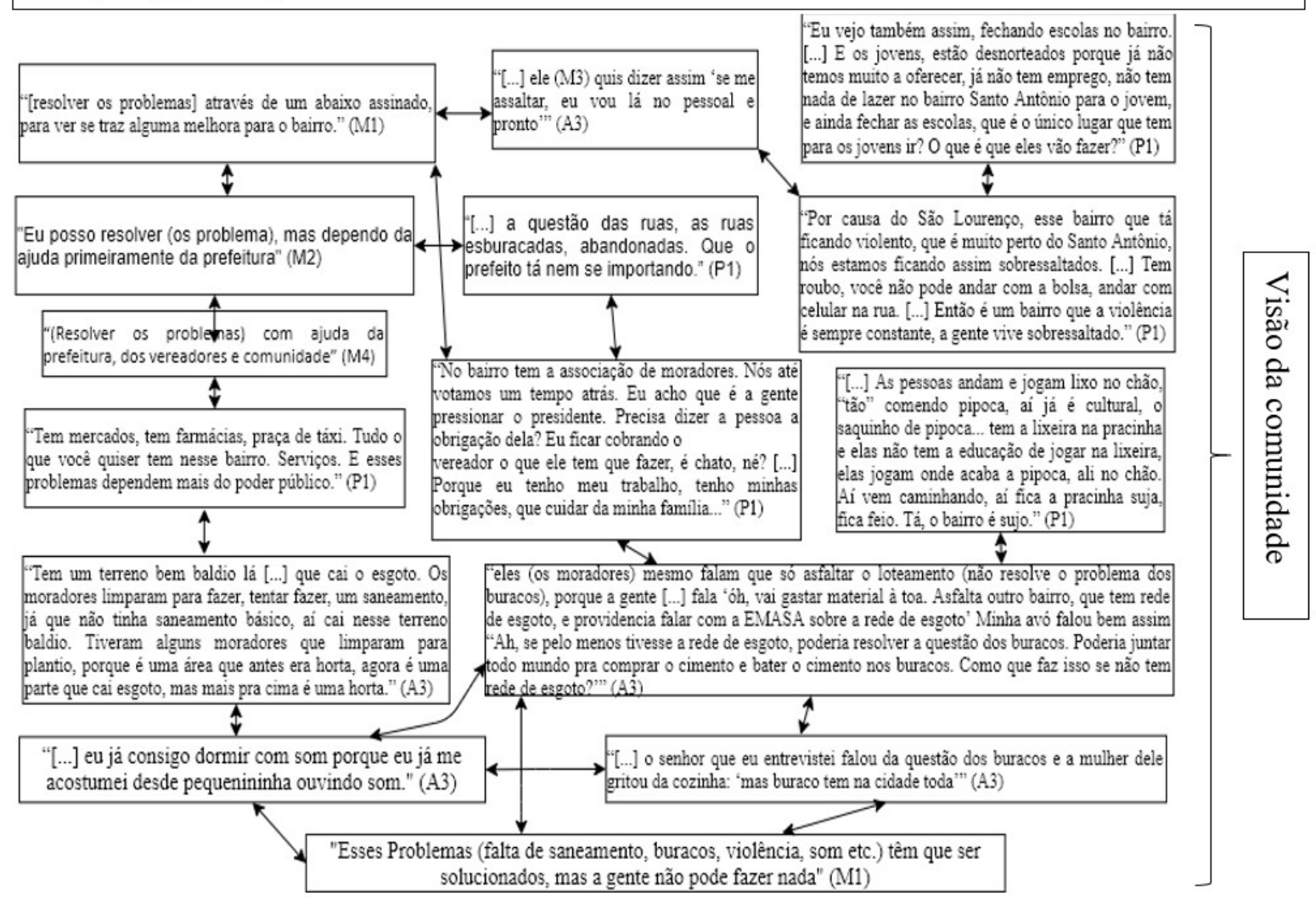


No topo da Rede Temática (Figura 2) há algumas marcações em cinza, que são assuntos relacionados ao problema da poluição sonora, situação problemática explicitada no Instrumento dialético-axiológico. Esses conteúdos em destaque podem ser organizados em Unidades de Ensino e trabalhados tanto em aulas de Ciências quanto no desenvolvimento de projetos no Clube de Ciências. As setas na Rede Temática possuem a função de evidenciar que entre os conceitos, conteúdos, conhecimento, práticas e ações existem relações, que ao serem visualizadas podem ajudar no processo de planejamento das atividades didático-pedagógicas.

Nesse sentido, a elaboração dos projetos de Ciências tem como direcionamento a investigação e a reflexão crítica acerca dos problemas existentes na realidade local, da qual os educandos e a comunidade escolar fazem parte. Esse direcionamento dialógico-problematizador no Clube de Ciências pode oportunizar um processo de ensino-aprendizagem que rompe com o entendimento equivocado de que a maior parte das atividades que envolvem a Educação Científica na escola necessitam de laboratórios, experimentos e a uma linguagem pouco compreensível popularmente (Borges, 2002). Como destacado por Auler (2002), a desmistificação da Ciência e o fomento a cultura de participação de diferentes atores sociais no Ensino de Ciências são imprescindíveis para a superação de uma compreensão salvacionista da Ciência, do determinismo tecnológico e dos modelos de decisóes tecnocráticas.

Ao serem evidenciadas suas potencialidades no processo de desvelamento da realidade local, o Instrumento dialético-axiológico no Clube de Ciências pode propiciar um entendimento das complexidades das relaçôes entre Ciência, Tecnologia e Sociedade, pois o desenvolvimento dos projetos necessita tanto dos conhecimentos científicos e tecnológicos para solucionar os problemas na comunidade quanto da compreensão histórica, social, política e econômica que os originam. À vista disso, considerar os valores das culturas locais no ensino-aprendizagem das Ciências é uma questão que tem chamado à atenção de pesquisadores que discutem CTS no contexto brasileiro, porquanto a constituição de um modelo de Ciência e Tecnologia originário do povo que a produz só é possível quando se compreende quais são os valores, demandas e necessidades de uma determinada realidade social (Roso, 2017).

A proposta construída entre o GEATEC e o Clube de Ciências do CIOMF se fundamenta no princípio da conscientização, para que educadores, educandos e a comunidade desenvolva um trabalho colaborativo e compreendam que as contradiçôes sociais possuem dimensôes valorativas, históricas, políticas e culturais que se perpetuam em um sistema que funciona com base nas relaçóes de dominação de classes sociais opressoras sobre grupos socialmente oprimidos (Freire, 2001). Os projetos desenvolvidos no Clube de Ciências do CIOMF partem de um compromisso ético-crítico de oportunizar um desenvolvimento mútuo da consciência e a participação comunitária na elaboração de alternativas às contradições sociais, como "exercício de voz, de ter voz, de ingerir, de decidir em certos níveis de poder, enquanto direito de cidadania” (Freire, 2001, p. 37).

No CIOMF, ao serem trabalhados conceitos científicos como som, ondas, acústica, decibéis, unidades de medida, materiais e força, que possuem relação com a cultura dos "paredôes" na região, ${ }^{3}$ causando o problema da poluição sonora, inicia-se a práxis axiológica transformadora, pois os conhecimentos construídos no âmbito escolar estão intimamente ligados aos valores e desvalores atribuídos às situações problemáticas existentes na realidade dos educandos. Esse comprometimento com um sistema educativo em que são consideradas tanto as demandas sociais quanto a percepção dos sujeitos sobre a própria condição existencial, caracteriza a Educação Científica ético-crítica, na qual se admite a indissociabilidade entre as dimensões epistemológica e axiológica no processo de construção dos conhecimentos.

\section{ALGUMAS CONSIDERAÇÕES}

O Instrumento dialético-axiológico foi elaborado com o objetivo de viabilizar a identificação dos valores e desvalores quem emergem da compreensão dos sujeitos sobre determinada situação ou objeto (Hessen, 1974; Lucas 2014; Patrício, 1993). Tal princípio possibilita o desvelamento de um pensamento coletivo que 
se expressa por meio de falas significativas, pois a dimensão axiológica é indissociável das dimensões histórica, política e material (Santos et al., 2019; Silva, 2004).

Com este estudo propõem-se que a seleção das falas significativas, realizada com base nos critérios indicados por Silva (2004), pode ser complementada com a utilização do Instrumento dialético-axiológico na organização das falas de acordo com os valores e desvalores que os sujeitos atribuem a uma situação problemática em comum. O Instrumento pode contribuir no processo de Codificação e Descodificação, garantindo que o problema, identificado na comunidade foco da Investigação Temática, esteja verdadeiramente relacionado à necessidade ou demanda percebida pelo sujeito em situação de opressão, o que viabilizará a elaboração de alternativas e estratégias que vão implicar numa transformação da realidade desse sujeito.

É importante destacar que o Instrumento dialético-axiológico não se reduz à identificação de um problema a ser abordado em sala de aula. Seus aportes teórico-metodológicos permitem uma análise axiológica, em diferentes níveis e contextos, que propicia uma compreensão crítica da realidade. Com a identificação dos valores e desvalores associados às contradições sociais, o instrumento apresenta possíveis contribuições no âmbito de uma organização curricular ético-crítica, do desenvolvimento de ações transformadoras, de processos avaliativos humanizados, da formação de professores comprometidos com o processo de libertação, dentre outras potencialidades que serão exploradas em estudos futuros.

No CIOMF, o Instrumento dialético-axiológico contribuiu para a identificação de valores e desvalores que revelaram a situação da poluição sonora como um exemplo de problema compartilhado pela comunidade do Santo Antônio. Após a organização da Rede Temática, foi possível sistematizar alguns conhecimentos e conteúdos de Ciências fundamentais para a compreensão do problema. Com isso, seja nas aulas de Ciências ou no Clube de Ciências, o trabalho desenvolvido no CIOMF contempla as dimensóes epistemológica e axiológica, viabilizando um processo de ensino-aprendizagem com sentido e significado aos educandos, garantindo que o ponto de partida seja o problema indicado e legitimado pelo outro (educando e sua comunidade) (Brick, 2017).

O reconhecimento do outro, numa relação educativa ético-crítica, é essencial para o desenvolvimento da cultura de participação, haja vista que tal atitude só é possível com a superação da cultura do silêncio. Nesse contexto, ao compreender que a educação é indispensável ao desenvolvimento social, científico e tecnológico, um processo condicionado por valores, o Instrumento dialético-axiológico se apresenta como um espaço de democratização das vozes distanciadas da escola por um sistema educacional tecnocrático e tradicional.

Por fim, ressalta-se que uma Educação Científica ético-crítica se caracteriza por: denunciar os mecanismos de dominação de um sistema hegemônico; promover a conscientização por meio do diálogo cultural entre os sujeitos de fora e de dentro da escola, propiciando um encontro de diferentes visóes de mundo; anunciar possibilidades e alternativas de superação das situaçóes denunciadas, que envolvem principalmente o silenciamento e invisibilização dos valores e do próprio ser das vítimas; considerar no Ensino de Ciências os valores e desvalores que emergem da realidade dos educandos; estabelecer uma relação necessária entre os conhecimentos científicos construídos no processo de escolarização e as demandas locais; se opor às práticas educativas que perpetuam uma concepção neutra e imparcial de Ciência e Tecnologia.

\section{AGRADECIMENTOS}

Os autores agradecem ao Conselho Nacional de Desenvolvimento Científico e Tecnológico (CNPq) e à Fundação de Amparo à Pesquisa do Estado da Bahia (FAPESB) pelo apoio financeiro recebido. 


\section{REFERÊNCIAS}

ABBAGNANO, N. Dicionário de filosofia. 2a ed. São Paulo, Martins Fontes, 1998.

AGRA, L; NAKAGAWA, R. A cena do "paredão": festas móveis no Recôncavo da Bahia. Revista Landa, v. 9, n. 1, 2020. Disponível em: < https://revistalanda.ufsc.br/vol-9-n1-2020/>. Acesso em: 12 abr. 2021.

ANJOS, K. S.; SANTOS, E. S.; SCOFIELD, N.; FREITAS, B.; GEHLEN, S. T. Demandas sociais no Clube de Ciências: um olhar sobre as relaçôes tema-conteúdo. In: XVIII EPEF - Encontro de Pesquisa em Ensino de Física, 2020, Online. São Paulo: SBF, 2020. Disponível em: <https://sec.sbfisica.org.br/eventos/epef/xviii/programa/pesqAutor.asp>. Acesso em: 10 jan. 2021.

ARAÚJO, U. F. Pedagogia de projetos e direitos humanos: caminhos para uma educação em valores. Pró-Posições, v. 19, n. 2, 2008. Disponível em: < http://dx.doi.org/10.1590/S0103-73072008000200014>. Acesso em: 15 mai. 2020.

AULER, D. Cuidado! Um cavalo viciado tendo a voltar para o mesmo lugar. Curitiba: Appris, 2018.

AULER, D. Interações entre Ciência-Tecnologia-Sociedade no contexto da formação de professores de ciências. Tese (Doutorado em Educação) - Universidade Federal de Santa Catarina, Florianópolis, 2002.

AULER, D.; DALMOLIN, A. M. T.; FENALTI, V. S. Abordagem Temática: natureza dos temas em Freire e no enfoque CTS. Alexandria: Revista de Educação em Ciência e Tecnologia, v.2, n.1, p.67-84, 2009. Disponível em: <https://periodicos.ufsc.br/index.php/alexandria/article/view/37915/28952>. Acesso em: 10 mar. 2020.

BARRERE, A.; MARTUCCELLI, D. A escola entre a agonia moral e a renovação ética. Revista Educação É Sociedade, Campinas, n. 76, 2001. Disponível em: <https://www.scielo.br/pdf/es/v22n76/a14v2276.pdf>. Acesso em: 15 jan. 2020.

BRICK, E. M. Realidade ensino de Ciências. Tese (Doutorado em Educação Científica e Tecnológica) - Universidade Federal de Santa Catarina, Florianópolis, 2017.

BORGES, A. T. Novos rumos para o laboratório escolar de Ciências. Caderno Brasileiro de Ensino de Física, v. 19, n. 3, p. 291-313, 2002. Disponível em: <https://periodicos.ufsc.br/index.php/fisica/article/view/6607/6099>. Acesso em: 01 ago. 2020.

DELIZOICOV, D. Conhecimento, tensões e transições. Tese (Doutorado em Educação) - Universidade de São Paulo, São Paulo, 1991.

DelizoiCov, D.; ANGOTTI, J. A. P.; PERnAmbUCO, M. M. C. A. Ensino de Ciências: Fundamentos e Métodos. São Paulo: Cortez, 2011.

DEMARTINI, G. R.; SILVA, A. F. G. Abordagem Temática na Sistematização Curricular para o Ensino de Ciências: Gravidez na Adolescência em uma Escola Estadual do Município de Sorocaba SP. In: IX Encontro Nacional de Pesquisa em Educação em Ciências (ENPEC), Águas de Lindóia, 2013. Disponível em: <http://www.nutes.ufrj.br/ abrapec/ixenpec/atas/resumos/R1039-1.pdf>. Acesso em: 15 jun. 2020.

DUSSEL, E. Ética da libertação: na idade da globalização e da exclusão. Petrópolis: Editora Vozes, 2002.

DUSSEL, E. Filosofia da libertação na América Latina. São Paulo: Ediçôes Loyola, 1977.

DUSSEL, E. La pedagógica latinoamericana. Bogotá: Nueva América, 1980.

FERNANDES, S. Pedagogia crítica como práxis marxista humanista: perspectivas sobre solidariedade, opressão e revolução. Educação E̊ Sociedade, v. 37, n. 135, p. 481-496, 2016. Disponível em: <https://doi.org/10.1590/ES0101$73302016140795>$. Acesso em: 15 jun. 2020.

FREIRE, P. Pedagogia do Oprimido. 17a ed. Rio de Janeiro: Paz e Terra, 1987.

FREIRE, P. Pedagogia da autonomia: saberes necessários à prática educativa. São Paulo: Paz e Terra, 1996.

FREIRE, P. Politica e Educação. 5a ed. São Paulo: Cortez, 2001. 
FONSECA, K. N. Investigação Temática e a Formação Social do Espaço: construção de uma proposta com professores dos anos iniciais. Dissertação (Mestrado em Educação em Ciências) - Universidade Estadual de Santa Cruz, Ilhéus, 2017.

GADAMER, H. G. Verdade e Método I: Traços fundamentais de uma hermenêutica filosófica. Petrópolis: Vozes, 2008.

GOERGEN, P. Educação e valores no mundo contemporâneo. Educação E̊ Sociedade, Campinas, v. 26, n. 92, p. 983-1011, 2005. Disponível em: <https://www.scielo.br/pdf/es/v26n92/v26n92a13.pdf>. Acesso em: 20 abr. 2020.

HESSEN, J. Filosofia dos valores. Coimbra: Armênio Amado, 1974.

LUCAS, L. B. Axiologia Relacional Pedagógica e a formação inicial de professores de Biologia. Tese (Doutorado em Educação de Ciências e Educação Matemática) - Universidade Estadual de Londrina, Londrina, 2014.

LUCAS, L. B.; PASSOS, M. M.; ARRUDA, S. M. A não neutralidade axiológica do processo de formação inicial de professores de biologia. Revista Brasileira de Pesquisa em Educação em Ciências, v. 16, p. 499-520, 2016. Disponível em: <https://periodicos.ufmg.br/index.php/rbpec/article/view/4475>. Acesso: 15 jun. 2020.

NASCIMENTO, T. G.; VON LINSINGEN, I. Articulaçốes entre o enfoque CTS e a pedagogia de Paulo Freire como base para o ensino de ciências. Convergência, v. 13, n. 42, p. 95-116, 2006. Disponível em: <http://www.scielo.org.mx/ pdf/conver/v13n42/v13n42a6.pdf>. Acesso em: 04 mar. 2020.

MENDONÇA, A. R. A aposta da reorientação curricular via Tema Gerador no Projeto Parnamirim Interdisciplinar. Dissertação (Mestrado em Educação) - Universidade Federal do Rio Grande do Norte, Natal, 2016.

MILLI, J. C. L.; ALMEIDA, E. S.; GEHLEN, S. T. A Rede Temática e o Ciclo Temático na Busca pela Cultura de Participação na Educação CTS. Alexandria: Revista de Educação em Ciências e Tecnologia, Florianópolis, v. 11, n. 1, p. 71-100, maio, 2018. Disponível em: <https://periodicos.ufsc.br/index.php/alexandria/article/view/19825153.2018v11n1p71>. Acesso em: 15 jun. 2020.

MIRANDA, A. C. G.; BRAIBANTE, M. E. F.; PAZINATO, M. S. Tema Gerador como estratégia metodológica para a construção do conhecimento em química e biologia. Experiências em Ensino de Ciências, v. 10, n. 1, p. 98-113, 2015. Disponível em: < http://if.ufmt.br/eenci/artigos/Artigo_ID267/v10_n1_a2015.pdf>. Acesso em: 15 jun. 2020.

PATRÍCIO, M. Liçôes de axiologia educacional. Lisboa: Universidade Aberta, 1993.

PEREIRA, A. L.; CLOCK, L. M.; LUCAS, L. B.; PASSOS, M. M. Educação em valores: possibilidades e responsabilidades na percepção de docentes que atuam na educação pública do estado do Paraná. Revista Tempos e Espaços em Educação, São Cristóvão, v. 10, n. 22, p. 23-34, 2017. Disponível em: <http://dx.doi.org/10.20952/revtee. v10i22.6167>. Acesso em: 15 jun. 2020.

PIRES, M. F. C. O Materialismo histórico-dialético e a educação. Revista Interface: Comunicação, Saúde, Educação, v.1, n.1, 1997. Disponível em: <http://dx.doi.org/10.1590/S1414-32831997000200006>. Acesso em: 05 jun. 2020.

RAICIK, A. C.; ANGOTTI, J. A. P. A escolha teórica em controvérsias científicas: valores e seus juízos à luz das concepçốes Kuhnianas. Alexandria: Revista de Educação em Ciência e Tecnologia, Florianópolis, v. 12, n. 1, p. 331349, 2019. Disponível em: <https://doi.org/10.5007/1982-5153.2019v12n1p331>. Acesso em 15 jun. 2020.

ROSA, S. E. Não Neutralidade da Ciência-Tecnologia: problematizando silenciamentos em práticas educativas relacionadas a CTS. Dissertação (Mestrado em Educação) - Universidade Federal de Santa Maria, Santa Maria, 2014.

ROSO, C. C. Transformaçốes na Educação CTS: uma proposta a partir do conceito de Tecnologia Social. Tese (Doutorado em Educação Científica e Tecnológica) - Universidade Federal de Santa Catarina, Florianópolis, 2017.

ROSO, C. C.; SANTOS, R. A.; ROSA, S. E.; AULER, D. Currículo Temático fundamentado em Freire-CTS: engajamento de professores de física em formação inicial. Revista Ensaio: Pesquisa em Educação em Ciências, v.17, n. 2, p. 372-389, 2015. Disponível em: <https://www.scielo.br/pdf/epec/v17n2/1983-2117-epec-17-02-00372.pdf>. Acesso em: 15 jun. 2020. 
SANTOS, J. S.; LIMA, J. A.; BARBOSA, L. dos S.; GEHLEN, S. T. A dimensão axiológica na elaboração de uma Rede Temática na Educação Infantil: contribuiçôes para o Ensino de Ciências. Revista Brasileira de Pesquisa em Educação em Ciências, v. 19, p. 649-682, 2019. Disponível em: <https://periodicos.ufmg.br/index.php/rbpec/article/ view/12047>. Acesso em: 12 jun. 2020.

SANTOS, M. J. A dialogicidade no pensamento de Paulo Freire e de Hans Georg Gadamer e implicações na cultura escolar brasileira. Cadernos do PET Filosofia, v.5, n.10, 2014. Disponível em: <https://doi.org/10.26694/cadpetfil. v5i10.3271>. Acesso em: 10 jun. 2020.

SANTOS, R. A.; AULER, D. Práticas educativas CTS: busca de uma participação social para além da avaliação de impactos da Ciência-Tecnologia na Sociedade. Ciência E̊ Educação, v. 25, n. 2, p. 485-503, 2019. Disponível em: $<$ https://doi.org/10.1590/1516-731320190020013>. Acesso em: 02 jun. 2020.

SILVA, A. F. G. A construção do curriculo na perspectiva popular crítica: das falas significativas às práticas contextualizadas. Tese (Doutorado em Educação) - Pontifícia Universidade Católica de São Paulo, São Paulo, SP, 2004.

SOUSA, P. S. Argumentação centrada em questôes sócio-cientificas e educação problematizadora: possibilidades para o ensino de ciências. Dissertação (Mestrado em Educação em Ciência) - Universidade Estadual de Santa Cruz, Ilhéus, 2015.

VIRÃES, M. B. A. R. A. O Papel da Escola na Educação de Valores. Mestrado (Ciências da Educação) - Universidade Lusófona de Humanidades e Tecnologias, Lisboa, 2013.

\section{NOTAS}

1 Os Círculos de Cultura foram estratégias inicialmente utilizadas por Freire no desenvolvimento do seu projeto de alfabetização. Essa estratégia consistia na formação de grupos, espacialmente organizados em círculo, cujos componentes são moradores da comunidade foco da Investigação Temática. No processo de desenvolvimento do círculo de cultura realiza-se a dinâmica dialógica e dialética de codificação e descodificação da realidade, em que "aprende-se em 'reciprocidade de consciências'; não há professor, há um coordenador, que tem por função dar as informaçôes solicitadas pelos respectivos participantes e propiciar condiçốes favoráveis à dinâmica do grupo, reduzindo ao mínimo sua intervenção direta no curso do diálogo" (Freire, 1987, p. 6).

2 É importante ressaltar que para cada bairro foi elaborada uma Rede Temática, pois apesar de fazerem parte da mesma cidade e compartilharem de algumas situaçôes problemáticas em comum, possuem suas particularidades históricoculturais. No entanto, no presente estudo, apenas a Rede Temática do bairro Santo Antônio é apresentada, em razão de que o foco aqui é explicitar o propósito do Instrumento dialético-axiológico e não todo o processo de desenvolvimento da Investigação Temática em Itabuna/BA.

3 Os "paredôes" são equipamentos de som potentes e imponentes acoplados a um veículo. Geralmente são utilizados em festas promovidas, na maioria das vezes, por jovens de regióes periféricas, como meio de divulgação de comércios, produtos e eventos locais e de propaganda política no período das eleiçôes (Agra; Nakagawa, 2020).

\section{Jefferson da Silva Santos}

Licenciado em Filosofia pela Universidade Estadual de Santa Cruz (UESC). Especialista em Filosofia e História das Ciências pela UNYLEYA. Mestre em Educação em Ciências e Matemática (UESC). Doutorando no Programa de Pós-Graduação em Educação Científica e Tecnológica (PPGECT) da Universidade Federal de Santa Catarina (UFSC) em Florianópolis, SC, Brasil. Membro do Grupo de Estudos e Pesquisa sobre Abordagem Temática no Ensino de Ciências (GEATEC) e do Grupo de Investigação no Ensino de Química (GIEQ).

E-mail: thomasjefferson_br@hotmail.com

\section{Simoni Tormöhlen Gehlen}

Licenciada em Física pela Universidade Federal de Santa Maria (UFSM). Mestre em Educação nas Ciências pela Universidade Regional do Noroeste do Estado do Rio Grande do Sul (UNIJUÍ). Doutora em Educação Científica e Tecnológica pela Universidade Federal de Santa 
Catarina (UFSC). Professora adjunta lotada no Departamento de Ciências Exatas e Tecnológicas da Universidade Estadual de Santa Cruz (UESC) em Ithéus, BA, Brasil. Coordenadora do Grupo de Estudos sobre Abordagem Temática no Ensino de Ciências (GEATEC).

E-mail: stgehlen@gmail.com

Contato:

Jefferson da Silva Santos

Universidade Federal de Santa Catarina

Centro de Ciências da Educação

Programa de Pós-Graduação em Educação Científica e Tecnológica

Sala 205, Bloco B do CED

Campus Universitário Trindade,

Florianópolis - SC | Brasil

CEP 88.040-900

Telefone: (48) 3721-4181

E-mail: sec.ppgect@gmail.com ou coordenacao.ppgect@gmail.com

Editor responsável:

Glauco Santos Ferreira da Silva 